\title{
Impact of different methods of physical training in inflammatory cytokines of type 2 diabetes
}

\author{
Pedro Weldes da Silva Cruz*, Laisa Kalil Buarque, Denise Maria Martins Vancea, Moacir de Novaes Lima Ferreira
}

From 20th Brazilian Diabetes Society Congress

Porto Alegre, Brazil. 11-18 November 2015

\section{Background}

Changes in the levels of inflammatory cytokines such as tumor necrosis factor (TNF- $\alpha$ ) and adiponectin may contribute to the aggravation of inflammatory processes the incidence increasing in 55\% of cardiovascular events in diabetic patients. Exercise is indicated as part of diabetes treatment. According to the American Diabetes Association, various kinds of methods should compose a physical training program for diabetics, but the most used protocols are the aerobic and resistance, with fiw protocols that use the method of combined training.

\section{Objective}

To identify which training method is more effective in relation to levels of proinflammatory cytokines and anti inflammatory type 2 diabetics.

\section{Materials and methods}

Study experimental nondandomized was approved by the Ethics Committee in Research of the Hospital Complex HUOC-PROCAPE/UPE on CAAE: 0154.0.106.000.11. 30 individuals with T2D were recruited who are part of the Sweet Life program Supervised Exercise Program for Diabetics the ESEF/UPE. The subjects were divided into 3 groups: Aerobic-GA $\mathrm{n}=10$ which held $40 \mathrm{~min}$. walk; Resisted-GR $\mathrm{n}=10$ which held 8 strength exercises, and Combined -GC $\mathrm{n}=10$ which held 20 min from GA and GR. The training program was performed 3 times a week for 24 weeks. The determination of cytokines (TNF- $\alpha$ and Adiponectin) was performed by Enzyme -Linked Immunosorbent Assay (ELISA). Analyzes of fasting glucose (8-12 $\mathrm{h}$ fasting). Blood postprandial glucose were also performed (after 1 hour of a standardized meal of $300 \mathrm{Kcal}$ ) made in the same intervals of cytokines by means of

\begin{tabular}{|c|c|c|c|c|c|c|c|c|c|}
\hline \multirow{3}{*}{ Variáveis } & \multicolumn{9}{|c|}{ GRUPOS } \\
\hline & \multicolumn{3}{|c|}{ GR } & \multicolumn{3}{|c|}{ GA } & \multicolumn{3}{|c|}{$\mathrm{GC}^{-}$} \\
\hline & Pré & Pós & P & Pre & Pós & $\mathbf{p}$ & Pré & Pás & P \\
\hline GJ (mg/dL) & $135 \pm 38,5$ & $122,1 \neq 23,7$ & 0,901 & $144,5 \$ 40,3$ & $133,8 \pm 39,2$ & $0.042^{*}$ & $126 \pm 20,2$ & $111,9 \pm 19,1$ & $0,002^{*}$ \\
\hline GPP (mg/dL) & $205,5+49,0$ & $176,7 \pm 29,05$ & $0,045^{*}$ & $209,2 \pm 51,7$ & $193,9 \pm 57,4$ & 0.162 & $173 \pm 51,6$ & $153,6 \pm 34$ & $0,031^{*}$ \\
\hline Gep (mg/diL) & $160,3 \pm 36,1$ & $117,6 \pm 26$ & $0,034^{*}$ & $179.1 \pm 36$ & $114,4 \pm 37,3$ & $0,045^{*}$ & $160,2 \pm 47,4$ & $111,5 \pm 32,4$ & $0,000^{*}$ \\
\hline TNF- $\alpha(\mu \mathrm{g} / \mathrm{ml})$ & $13,0=1,54$ & $12,35 \pm 1,56$ & 0,09 & $12,7 \pm 1,32$ & $11,4=1,16$ & $0,001^{*}$ & $13,7 \pm 1,62$ & $12,8 \pm 1,62$ & $0,000^{\circ}$ \\
\hline Adiponectina ( $\mu \mathrm{g} / \mathrm{ml}$ ) & $1,34 \pm 0,38$ & $1,28 \pm 0,40$ & 0,154 & $1,32 \pm 0,23$ & $1,29 \pm 0,22$ & 0,220 & $1,23 \pm 0,28$ & $1,24 \pm 0,31$ & 0,243 \\
\hline
\end{tabular}

Figure 1 Metabolic profile of type 2 diabetics undergoing different types of training.

\footnotetext{
* Correspondence: pedro.esef@yahoo.com.br

Faculdade de Ciências Médicas de Pernambuco, Recife, Brazil
}

(c) 2015 da Silva Cruz et al. This is an Open Access article distributed under the terms of the Creative Commons Attribution License (http://creativecommons.org/licenses/by/4.0), which permits unrestricted use, distribution, and reproduction in any medium, provided the original work is properly cited. The Creative Commons Public Domain Dedication waiver (http://creativecommons.org/ publicdomain/zero/1.0/) applies to the data made available in this article, unless otherwise stated. 
capillary glucose using Brezze2 glucometer from Bayer. Data were analyzed by non-parametric Wilcoxon test and Kruskal-Wallis beyond the Pearson Correlation, adopting a significance level of $\mathrm{p} \leq 0.05$.

\section{Results}

The sample consisted mostly of women $(n=25)$, mean age 66.4 \pm 8.7 yrs. When analyzing the impact of different training protocols on cytokines, the GR did not show changes in cytokine analyzed. In the intergroup analysis GA and GC showed a significant improvement in the values of TNF- $\alpha$ after the intervention (GA $12.7 \pm 1.32$ vs $11.4 \pm 1.16 \mathrm{mg} / \mathrm{mL} \mathrm{p}=0.001$ and $13.7 \pm \mathrm{GC} 1.62$ vs. $12.8 \pm 1.62 \mathrm{mg} / \mathrm{mL} \mathrm{p}=0.000$ ). There were no changes in adiponectin values after application of physical training protocol.

\section{Conclusion}

The protocol of combined training showed greater efficiency in regulating the levels of TNF- $\alpha$ in this sample, with a greater emphasis on aerobic training.

Published: 11 November 2015

doi:10.1186/1758-5996-7-S1-A229

Cite this article as: da Silva Cruz et al:: Impact of different methods of physical training in inflammatory cytokines of type 2 diabetes.

Diabetology \& Metabolic Syndrome 2015 7(Suppl 1):A229.

Submit your next manuscript to BioMed Central and take full advantage of:

- Convenient online submission

- Thorough peer review

- No space constraints or color figure charges

- Immediate publication on acceptance

- Inclusion in PubMed, CAS, Scopus and Google Scholar

- Research which is freely available for redistribution

Submit your manuscript at www.biomedcentral.com/submit 